\title{
Hyperprolactinemia has no effect on plasma ghrelin levels in patients with prolactinoma
}

\author{
Tuncay Delibaşı ${ }^{1}$, Müyesser Sayki Arslan ${ }^{1}$, Erman Çakal ${ }^{1}$, Mustafa Şahin², Oya Topaloğlu ${ }^{1}$, Esra Tutal ${ }^{1}$, Ilknur Öztürk Ünsal ${ }^{1}$,

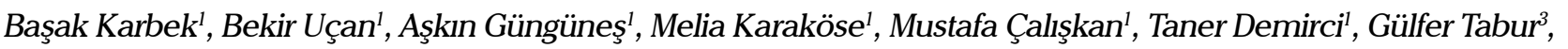 \\ Mustafa Özbek ${ }^{1}$ \\ 'Department of Endocrinology and Metabolism, Dişkapı Training and Research Hospital, Ankara, Turkey \\ ${ }^{2}$ Department of Endocrinology and Metabolism, Ankara University Faculty of Medicine, Ankara, Turkey \\ ${ }^{3}$ Department of Biochemistry, Diskkapı Training and Research Hospital, Ankara, Turkey
}

\section{Abstract}

Objective: Accumulating evidence suggests that prolactin is a modulator of body weight and composition and that it regulates some transporters in adipose tissue. It was demonstrated that hyperprolactinemia is associated with weight gain and obesity. Ghrelin is a novel hormone secreted from many organs including the pituitary gland. Ghrelin acts by regulating energy homeostasis and stimulating appetite. The aim of this study is to investigate whether ghrelin has a role in the case of weight gain in patients with prolactinoma.

Material and Methods: Forty-four patients with prolactinoma, both newly diagnosed and undergoing cabergoline treatment, were included in this study. Age- and sex-matched healthy subjects were included in the control group. Serum fasting glucose, insulin, lipid profile, and ghrelin levels were measured. Homeostasis model assessment of insulin resistance (HOMA-IR) was also calculated. Body mass index (BMI) and total fat ratio (\%) of all the participants were assessed by bioelectrical impedance analysis using TBF-310GS ${ }^{\mathrm{TM}}$ (Tanita Corporation, Tokyo, Japan).

Results: Patients with prolactinoma demonstrated significantly higher serum levels of fasting insulin, triglyceride, and waist and hip circumference measurement. No significant difference was found between the fasting glucose, high-density lipoprotein cholesterol, low-density lipoprotein cholesterol, and HOMA-IR levels. BMI was significantly higher in the patients with prolactinoma than that in the control group ( $<<0.05$ ). Additionally, the total body fat percentage was higher in the patients with prolactinoma than that in the control group; however, the difference was not significant $(p>0.05)$. Furthermore, there was no significant difference in terms of the ghrelin levels between these groups. There was a correlation with serum ghrelin and growth hormone levels $(\mathrm{p}<0.02$, rho $=0.489)$. However, no significant correlation was obtained between serum prolactin or ghrelin levels and body fat percentage.

Conclusion: According to the results of our study, ghrelin has no effect on weight gain in patients with prolactinoma. Further studies are needed to evaluate whether ghrelin affects the prevalence of obesity in patients with prolactinoma. (J Turk Ger Gynecol Assoc 2015; 16: 86-90)

Keywords: Hyperprolactinemia, ghrelin, weight gain

Received: 19 February 2015

Accepted: 24 March 2015

\section{Introduction}

Accumulating evidence suggests that prolactin is a modulator of body weight and composition and that it regulates transporters and enzymes in the adipose tissue and islets. Kok et al. (1) reported that increased prolactin secretion was demonstrated by serial prolactin measurements over $24 \mathrm{~h}$ in obese women compared with those in lean subjects and that a proportional prolactin release is seen with an increasing body mass index (BMI) and size of visceral fat mass. Several studies reported that hyperprolactinemia is associated with weight gain, obesity, and insulin resistance (1-7). However, the mechanism by which hyperprolactinemia may cause weight gain and obesity is not clear. Two of the main potential reported explanations are the disruption of the central nervous system dopaminergic tone and the stimulation of lipo- genesis (8). However, whether prolactin is directly related to weight gain or the consequences of the central dopaminergic effect is not clear.

Ghrelin, which is known as the ligand of the growth hormone secretagogue receptor (GHS-R), is a circulating orexigenic and adipogenic brain-gut peptide. According to recent studies, ghrelin is produced from several organs, such as the intestine, kidney, placenta, pituitary gland, hypothalamus, lung, lymphatic tissue, thyroid gland, adrenal gland, and gonads $(9,10)$. Ghrelin regulates the function of the anterior pituitary gland by stimulating the growth hormone, adrenocorticotropin, and prolactin, and it also modulates the functions of the exocrine and endocrine pancreas (11). Its effect on the regulation of energy balance and appetite is through the signaling GHS-R in the brain. Interestingly, ghrelin is expressed in a variety of pituitary adenomas (12). Rotondo et al. (13) noted that the highest ghre- 
lin expression is found in growth hormone-producing adenomas exposed to long-acting somatostatin analogs. In their study, they found a lower ghrelin expression in Cushing's disease, untreated growth hormone adenomas, and dopamine agonist-treated prolactinomas. However, no significant immunoreactivity was found in untreated prolactinomas. In conditions of anorexia nervosa, bulimia nervosa, obesity, and polycystic ovary syndrome, prolactin and growth hormone are released as a response to exogenous ghrelin. Messini et al. (14) demonstrated that bromocriptine blocks the stimulating effect of ghrelin on prolactin release in healthy premenapousal women.

Ghrelin has been reported to cause over eating by stimulating appetite resulting in increased body weight. Decreased ghrelin levels are associated with insulin resistance and abdominal adiposity in type 2 diabetes mellitus. Low ghrelin levels are found in obesity, acromegaly, and hypothyroidism associated with Hashimoto's thyroiditis (15-18). There are inadequate data in literature about the relationship between ghrelin and prolactin levels. Additionally, there is no study about ghrelin levels in patients with prolactinoma. Hence, we decided to examine whether circulating ghrelin levels in prolactinoma patients, both newly diagnosed and undergoing therapy, differ from those in healthy subjects in the present study.

\section{Material and Methods}

Forty-four patients with prolactinoma, both newly diagnosed and undergoing cabergoline treatment, were included in this study. The diagnosis of prolactinoma was based on increased serum prolactin levels and was located by magnetic resonance imaging of the pituitary gland that indicated an adenoma. Patients with hyperprolactinemia caused by other reasons and hypopituitarism were excluded. None of the patients had any endocrinopathy except hyperprolactinemia. Thirty-six patients were women, and eight were men. Eleven patients had macroprolactinoma, and thirty-three had microprolactinoma. Thirty-two healthy volunteers, without any metabolic diseases, of similar age and gender served as the control group $(\mathrm{p}=0.6)$. Participants with a history of metabolic disease, endocrine obesity, and those who took any medical or herbal drug that could affect metabolic parameters were excluded from the study. Additionally, we excluded participants with a history of eating disorders and weight loss. The hospital ethics committee evaluated and approved the study, and all participants gave informed consent.

Serum fasting glucose, low-density lipoprotein (LDL) cholesterol, high-density lipoprotein (HDL) cholesterol, and triglyceride concentrations were evaluated using enzymatic commercial kits. Prolactin and insulin levels were evaluated by a chemiluminescence assay (Advia Centaur, Siemens Healthcare diagnostics, USA). Intra- and inter-assay variation coefficients were $4.6 \%, 3.2 \%$, and $3.3 \%$ and $5.9 \%, 2.6 \%$, and $4.8 \%$ for 14.68 $\mathrm{mU} / \mathrm{L}, 45.72 \mathrm{mU} / \mathrm{L}$, and $124.51 \mathrm{mU} / \mathrm{L}$ of insulin, respectively. The intra-assay variation coefficient was $2.3 \%$ and $2.8 \%$ for $10.2 \mathrm{ng} /$ $\mathrm{mL}$ and and $60.4 \mathrm{ng} / \mathrm{mL}$ of prolactin, respectively, whereas the inter-assay variation coefficient was $2.0 \%$ and $3.4 \%$ for $10.2 \mathrm{ng} /$ $\mathrm{mL}$ and and $60.4 \mathrm{ng} / \mathrm{mL}$ of prolactin, respectively. The normal limits of prolactin levels were $2.7-18.3 \mathrm{ng} / \mathrm{mL}$.
Blood samples for ghrelin measurement levels were collected into the tubes containing EDTA. The blood was centrifuged at $1.600 \times \mathrm{g}$ for $15 \mathrm{~min}$; the plasma was separated and stored at $-80^{\circ} \mathrm{C}$ until assessment of ghrelin. The measurements of ghrelin levels were performed in an EPOCH system (BioTek Instruments Inc., Winooski, USA) using the commercially available enzyme-linked immunosorbent assay kit (Phoenix Pharmaceuticals, California, USA) in accordance with the manufactures' instructions. The assay range of the ghrelin ELISA kit was $0-100 \mathrm{ng} / \mathrm{mL}$. The blood samples of both groups were measured simultaneuosly for ghrelin levels.

Waist and hip diameter was measured. BMI and homeostasis model assessment of insulin resistance (HOMA-IR) were calculated (19). The total fat ratio (\%) of all the participants was assessed by bioelectrical impedance analysis (BIA) using TBF310GS ${ }^{\mathrm{TM}}$ (Tanita Corporation, Tokyo, Japan) and was recorded. Descriptive data from the measurements obtained were presented as numbers and arithmetic mean \pm SD. KolmogorovSmirnov test was used to test the normality of distribution for numerical data. Student's t-test and chi-square test were used to compare the two groups. Association among the numerical data was detected by Pearson correlation analysis. Using multivariate multiple regression, backward elimination was used to determine the association between the ghrelin and numerical measurements. $\mathrm{P}<0.05$ was considered statistically significant. PASW version 18, (SPSS, Chicago, IL, USA) software was used for the statistical calculations.

\section{Results}

Demographic characteristics and biochemical data of the patients and healthy subjects are summarized in Table 1. Nineteen patients were newly diagnosed, and 25 patients were undergoing cabergoline treatment (mean duration since diagnosis, 35 months; range, 6-192 months). Only two patients had a transnasal transsphenoidal operation for macroprolactinoma. Compared with the age- and gender-matched control subjects, the patients with prolactinoma demonstrated significantly higher serum levels of fasting insulin, HOMA-IR, triglyceride, and waist and hip circumference measurement. No significant difference was found between fasting glucose, HDL-cholesterol, and LDL-cholesterol levels (Table 1). In the results of TANITA analysis, the total body fat percentage was higher in patients with prolactinoma compared with that in the healthy subjects; however, the difference was not significant $(34.9 \pm 7.6 \%$ vs $31.3 \pm 7.3 \%, p=0.131)$. Furthermore, there was no significant difference in terms of the ghrelin levels between the patients with prolactinoma both newly diagnosed and undergoing cabergoline treatment and the healthy subjects (Table 2). Thyroid-stimulating hormone levels were similar in the groups $(\mathrm{p}=0.182)$. Estrogen levels were compared in female participants and were found to be $81.6 \pm 66.5 \mathrm{pg} / \mathrm{mL}$ and $58.7 \pm 73.9 \mathrm{pg} / \mathrm{mL}$ in the controls and patients, respectively $(\mathrm{p}=0.39)$. Growth hormone and somatomedin-C levels were $0.5 \pm 1.1 \mathrm{pg} / \mathrm{mL}$ and $176.1 \pm 76.2 \mathrm{pg} / \mathrm{mL}$, respectively in the patient group. 
Table 1. Demographic characteristics and biochemical data for patients and control subjects

\begin{tabular}{|l|c|c|c|}
\hline & $\begin{array}{c}\text { Patients } \\
(\mathbf{n = 4 4})\end{array}$ & $\begin{array}{c}\text { Controls } \\
(\mathbf{n = 3 2})\end{array}$ & $\mathbf{p}$ \\
\hline Male/female & $8 / 36$ & $5 / 27$ & 0.51 \\
\hline Age (years) & $38.7 \pm 10.3$ & $40.9 \pm 8.4$ & 0.341 \\
\hline PRL (ng/mL) & $88.9 \pm 110.8$ & $8.7 \pm 3.8$ & 0.000 \\
\hline BMI $\left(\mathrm{kg} / \mathrm{m}^{2}\right)$ & $30.7 \pm 5.8$ & $26.9 \pm 3.9$ & 0.011 \\
\hline WC $(\mathrm{cm})$ & $93.3 \pm 14.1$ & $85.6 \pm 8.1$ & 0.018 \\
\hline HC $(\mathrm{cm})$ & $101.4 \pm 12.9$ & $83.4 \pm 8.8$ & 0.012 \\
\hline FBG $(\mathrm{mg} / \mathrm{dL})$ & $88.6 \pm 11.1$ & $84.2 \pm 75.9$ & 0.07 \\
\hline HDL-C $(\mathrm{mg} / \mathrm{dL})$ & $50.2 \pm 9.7$ & $53.2 \pm 19.9$ & 0.476 \\
\hline LDL-C $(\mathrm{mg} / \mathrm{dL})$ & $117.3 \pm 31.9$ & $114.3 \pm 34.9$ & 0.719 \\
\hline TG $(\mathrm{mg} / \mathrm{dL})$ & $123.5 \pm 54.2$ & $99.8 \pm 45.5$ & 0.050 \\
\hline Fasting insulin $(\mathrm{IU} / \mathrm{mL})$ & $12.3 \pm 7.3$ & $8.4 \pm 3.4$ & 0.013 \\
\hline HOMA-IR & $2.9 \pm 2.0$ & $1.6 \pm 0.6$ & 0.004 \\
\hline TSH & $2.08 \pm 0.9$ & $1.8 \pm 0.9$ & 0.182 \\
\hline BFP (\%) & $34.9 \pm 7.6$ & $31.3 \pm 7.3$ & 0.131 \\
\hline
\end{tabular}

*Data are presented as mean $\pm \mathrm{SD}$

PRL: prolactin; BMI: body mass index; WC: waist circumference; HC: hip circumference; FBG: fasting blood glucose; HDL-C: high-density lipoprotein cholesterol; LDL-C: low-density lipoprotein cholesterol; TG: triglyceride; HOMA-IR: homeostasis model assessment of insulin resistance; TSH: thyroid-stimulating hormone; BFP: body fat percentage

Table 2. Ghrelin levels in patients and controls

\begin{tabular}{|l|c|c|}
\hline & Ghrelin $(\mathbf{p g} / \mathbf{m L})$ & $\mathbf{p}$ \\
\hline Patients with remission $(\mathrm{n}=19)$ & $24.4 \pm 15.5$ & \\
\hline Patients with new diagnosis $(\mathrm{n}=25)$ & $27.4 \pm 16.3$ & \\
\hline Controls $(\mathrm{n}=32)$ & $25.6 \pm 11.8$ & 0.795 \\
\hline
\end{tabular}

There was a positive correlation between serum ghrelin and growth hormone levels $(\mathrm{p}<0.02, \mathrm{rho}=0.489)$ in the correlation analysis. However, no significant correlation was obtained between serum prolactin or ghrelin levels and body fat percentage. Furthermore, a negative correlation was only found between ghrelin and fasting blood glucose levels, and a positive correlation was only found between ghrelin and HOMA-IR levels in multiple regression analysis $(\mathrm{p}=0.036, \mathrm{p}=0.037)$ (Figure 1, 2).

\section{Discussion}

Ghrelin is a circulating peptide having many effects on both metabolism and neuroendocrine functions including weight control and growth. It was demonstrated that ghrelin stimulates prolactin secretion from the pituitary gland in women (20). However, the mechanism is not explained very well. In addition, ghrelin levels in patients with prolactinoma have not been investigated yet. Our data has demonstrated for the first time that fasting serum ghrelin levels had no relationship with prolactin in patients diagnosed with prolactinoma. These data suggest that ghrelin levels have no significant effect on weight

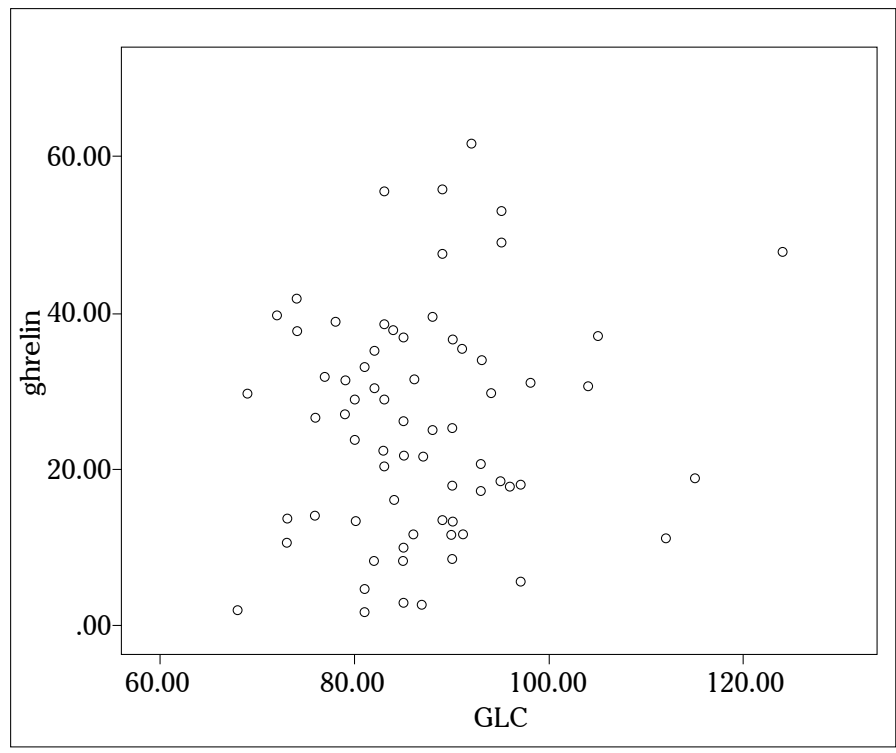

Figure 1. Relationship between levels of fasting serum ghrelin and glucose in patients with prolactinoma

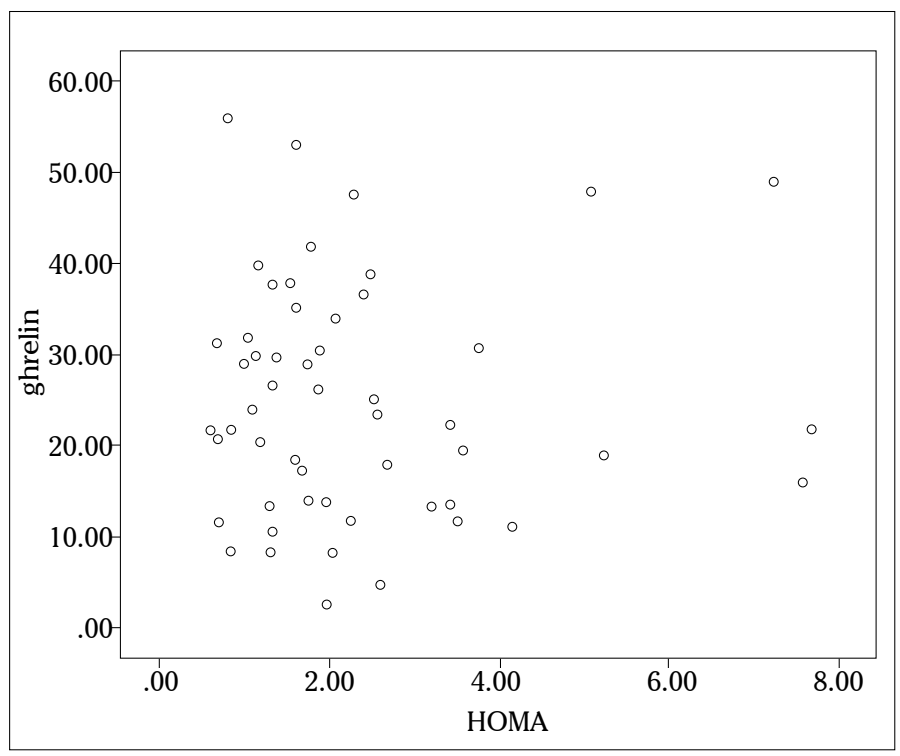

Figure 2. Relationship between levels of fasting serum ghrelin and HOMA-IR in patients with prolactinoma

gain and could not explain increased obesity prevalence in prolactinoma.

There are few studies conducted on the relation between prolactin and ghrelin levels. The stimulatory effect of ghrelin on prolactin secretion reflects the direct stimulation of somatomammotroph cells. In this study we found a positive correlation between serum ghrelin and growth hormone levels $(\mathrm{p}<0.02$, rho $=0.489)$ in the correlation analysis. Takaya et al. (21) demonstrated the stimulation of growth hormone, adrenocorticotropic hormone, cortisol, and prolactin after ghrelin injection. In another study, plasma total ghrelin values are found to be negatively correlated to IGF-I in patients with acromegaly (22). However, we found no significant correlation between serum prolactin and ghrelin levels. Furthermore, we evaluated the 
relation between ghrelin and body fat percentage and found no significant correlation.

We evaluated ghrelin levels in two groups of the patients with prolactinoma; one group had active prolactinoma and the other had patients under remission with cabergoline treatment. We found higher ghrelin levels in newly diagnosed patients; however, the difference was not statistically significant. Messini et al. (14) investigated the effect of bromocriptine, which is a dopamine agonist similar to cabergoline on ghrelin-induced prolactin secretion in healthy premenopausal women. They demonstrated that bromocriptine block the stimulating effect of ghrelin on prolactin release (14). Thus, the insignificant lower levels of ghrelin in patients with remission may be related to the cabergoline effect of ghrelin on prolactin levels.

Ghrelin levels increase by fasting and decrease by food intake and overfeeding (23). Therefore, all samples were collected after eight hours of fasting. Conflicting results about the effect of gender on ghrelin levels were reported. To eliminate the possible effect of gender, we included participants with a similar ratio of both genders. Ghrelin reduces insulin secretion in humans. Tschöp et al. (24) found a negative correlation between plasma ghrelin and insulin concentrations. Lucidi et al. (25) reported a clear reduction in circulating ghrelin levels with an increase in insulin levels during both hypoglycemic and euglycemic clamp 5 . In contrast, we did not observe any correlation between insulin and ghrelin levels. However, we found a negative correlation between ghrelin and fasting blood glucose levels and a positive correlation between ghrelin and HOMA-IR levels in multiple regression analysis.

Hyperprolactinemia is related to increased food intake and body weight in rats, and suppression of prolactin causes weight loss $(26,27)$. The mechanism of how hyperprolactinemia causes weight gain is not clear. Therefore, we investigated whether ghrelin was associated with increased food intake by stimulating appetite or other mechanisms and body weight. The participants in the present study had BMI $\geq 30 \mathrm{~kg} / \mathrm{m}^{2}$. They had significantly higher BMI than the controls; however, ghrelin levels were higher in the patients with prolactinoma. In contrast to our finding, Tschöp et al. (15) found circulating ghrelin levels in obese patients to be low. In patients with prolactinoma, it was found that the central dopaminergic tone is reduced because of the refractoriness of central dopaminergic neurons to prolactin, and it may contribute to weight gain in patients with prolactinoma (28). The central stimulation of dopamine receptors, either dopamine receptor 1 or dopamine receptors 2 and 3 simultaneously, leads to a significant decrease in ghrelininduced food intake (29).

It could be argued that the level of ghrelin was evaluated without performing dynamic test. We accept this as a limitation of our study. Another limitation is the evaluation of only total ghrelin levels without separately evaluating the levels of full length ghrelin (acyl plus des-acyl) and des-acyl ghrelin as recommended by Liu et al. (30).

In conclusion, ghrelin has no effect on weight gain in patients diagnosed with prolactinoma. Plasma ghrelin may not directly reflect the ghrelin level in the pituitary gland. Further larger studies are needed to determine the relation between prolactin and ghrelin on obesity in patients with prolactinoma.

Ethics Committee Approval: Ethics committee approval was received for this study from the ethics committee of Local Ethics Commitee, Dışkapı Teaching and Research Hospital.

Informed Consent: Written informed consent was obtained from patients who participated in this study.

Peer-review: Externally peer-reviewed.

Author Contributions: Concept - M.S.A., M.S., T.D.; Design - M.S.A., T.D.; Supervision - T.D., E.Ç., M.S..; Resource - T.D.; Materials - E.T., A.G., M.K., G.T.; Data Collection \& /or Processing - I.Ö.Ü., T.D., M.S.A., B.U.; Analysis \& /or Interpretation - M.S., O.T., M.S.A., M.Ö.; Literature Search - M.S.A., E.T., T.D.; Writing M.S.A., T.D., M.S., Critical Reviews - M.S., E.C.., T.D., M.S.A.

Conflict of Interest: No conflict of interest was declared by the authors.

Financial Disclosure: The authors declared that this study has received no financial support.

\section{References}

1. Kok P, Roelfsema F, Frölich M, Meinders AE, Pijl H. Prolactin release is enhanced in proportion to excess visceral fat in obese women. $\mathrm{J}$ Clin Endocrinol Metab 2004; 89: 4445-9. [CrossRef]

2. Galluzzi F, Salti R, Stagi S, La Cauza F, Chiarelli F. Reversible weight gain and prolactin levels--long-term follow-up in childhood. J Pediatr Endocrinol Metab 2005; 18: 921-4. [CrossRef]

3. Creemers LB, Zelissen PM, van 't Verlaat JW, Koppeschaar HP. Prolactinoma and body weight: a retrospective study. Acta Endocrinol (Copenh) 1991; 125: 392-6. [CrossRef]

4. Greenman Y, Tordjman K, Stern N. Increased body weight associated with prolactin secreting pituitary adenomas: weight loss with normalization of prolactin levels. Clin Endocrinol (Oxf) 1998; 48: 547-53. [CrossRef]

5. Schmid C, Goede DL, Hauser RS, Brändle M. Increased prevalence of high Body Mass Index in patients presenting with pituitary tumours: severe obesity in patients with macroprolactinoma. Swiss Med Wkly 2006; 136: 254-8.

6. Inancli SS, Usluogullari A, Ustu Y, Caner S, Tam AA, Ersoy R, Cakir B. Effect of cabergoline on insulin sensitivity, inflammation, and carotid intima media thickness in patients with prolactinoma. Endocrine 2013; 44: 193-9. [CrossRef]

7. Arslan MS, Topaloglu O, Sahin M, Tutal E, Gungunes A, Cakir E, et al. Preclinical atherosclerosis in patients with prolactinoma. Endocr Pract 2014; 20: 447-51. [CrossRef]

8. Doknic M, Pekic S, Zarkovic M, Medic-Stojanoska M, Dieguez C, Casanueva F, Popovic V. Dopaminergic tone and obesity: an insight from prolactinomas treated with bromocriptine. Eur J Endocrinol 2002; 147: 77-84. [CrossRef]

9. Korbonits M, Kojima M, Kangawa K, Grossman AB. Presence of ghrelin in normal and adenomatous human pituitary. Endocrine 2001; 14: 101-4. [CrossRef]

10. Ueberberg B, Unger N, Saeger W, Mann K, Petersenn S. Expression of ghrelin and its receptor in human tissues. Horm Metab Res 2009; 41: 814-21. [CrossRef]

11. Lim CT, Kola B, Korbonits M, Grossman AB. Ghrelin's role as a major regulator of appetite and its other functions in neuroendocrinology. Prog Brain Res 2010; 182: 189-205. [CrossRef] 
12. Leontiou CA, Franchi G, Korbonits M. Ghrelin in neuroendocrine organs and tumours. Pituitary 2007; 10: 213-25. [CrossRef]

13. Rotondo F, Cusimano M, Scheithauer BW, Rotondo A, Syro LV, Kovacs K. Ghrelin immunoexpression in pituitary adenomas. Pituitary 2011; 14: 318-22. [CrossRef]

14. Messini CI, Dafopoulos K, Chalvatzas N, Georgoulias P, Anifandis $\mathrm{G}$, Messinis IE. Blockage of ghrelin-induced prolactin secretion in women by bromocriptine. Fertil Steril 2010; 94: 1478-81. [CrossRef]

15. Tschöp M, Weyer C, Tataranni PA, Devanarayan V, Ravussin E, Heiman ML. Circulating ghrelin levels are decreased in human obesity. Diabetes 2001; 50: 707-9. [CrossRef]

16. Katsuki A, Urakawa H, Gabazza EC, Murashima S, Nakatani K, Togashi $\mathrm{K}$, et al. Circulating levels of active ghrelin is associated with abdominal adiposity, hyperinsulinemia and insulin resistance in patients with type 2 diabetes mellitus. Endocrinol 2004; 151: 573-7. [CrossRef]

17. Altinova AE, Toruner F, Karakoc A, Yetkin I, Ayvaz G, Cakir N, et al. Serum Ghrelin Levels in patients with Hashimoto's thyroiditis. Thyroid 2006; 16: 1259-64. [CrossRef]

18. Kawamata T, Inui A, Hosoda H, Kangawa K, Hori T. Perioperative plasma active and total ghrelin levels are reduced in acromegaly when compared with in nonfunctioning pituitary tumours even after normalization of serum GH. Clin Endocrinol (Oxf) 2007; 67: 140-4. [CrossRef]

19. Matthews DR, Hosker JP, Rudenski AS, Naylor BA, Treacher DF, Turner RC. Homeostasis model assesment: insulin resistance and beta-cell function from fasting blood glucoseand insuln concentrations in man. Diabetologia 1985; 28: 412-9. [CrossRef]

20. Broglio F, Benso A, Castiglioni C, Gottero C, Prodam F, Destefanis $\mathrm{S}$, et al. The endocrine response to ghrelin as a function of gender in humans in young and elderly subjects. J Clin Endocrinol Metab 2003; 88: 1537-42. [CrossRef]
21. Takaya K, Ariyasu H, Kanamoto N, Iwakura H, Yoshimoto A, Harada $\mathrm{M}$, et al. Ghrelin strongly stimulates growth hormone release in humans. J Clin Endocrinol Metab 2000; 85: 4908-11. [CrossRef]

22. Jarkovská Z, Rosická M, Marek J, Hána V, Weiss V, Justová V, et al. Plasma levels of total and active ghrelin in acromegaly and growth hormone deficiency. Physiol Res 2006; 55: 175-81.

23. Cummings DE, Schwartz MW. Genetics and pathophysiology of human obesity. Annu Rev Med 2003; 54: 453-71. [CrossRef]

24. Tschöp M, Weyer C, Tataranni PA, Devanarayan V, Ravussin E, Heiman ML. Circulating ghrelin levels are decreased in human obesity. Diabetes 2001; 50: 707-9. [CrossRef]

25. Lucidi P, Murdolo G, Di Loreto C, De Cicco A, Parlanti N, Fanelli C, et al. Ghrelin is not necessary for adequate hormonal counterregulation of insulin-induced hypoglycemia. Diabetes 2002; 51: 2911-4. [CrossRef]

26. Moore BJ, Gerardo-Gettens T, Horwitz BA, Stern JS. Hyperprolactinemia stimulates food intake in the female rat. Brain Res Bull 1986; 17: 563-9. [CrossRef]

27. Byatt JC, Staten NR, Salsgiver WJ, Kostelc JG, Collier RJ. Stimulation of food intake and weight gain in mature female rats by bovine prolactin and bovine growth hormone. Am J Physiol 1993; 264: E986-92.

28. Ben-Jonathan N, Hnasko R. Dopamine as a prolactin (PRL) inhibitor. Endocr Rev 2001; 22: 724-63. [CrossRef]

29. Romero-Picó A, Novelle MG, Folgueira C, López M, Nogueiras R, Diéguez C. Psychopharmacology (Berl). Central manipulation of dopamine receptors attenuates the orexigenic action of ghrelin. Psychopharmacology (Berl) 2013; 229: 275-83. [CrossRef]

30. Liu J, Prudom CE, Nass R, Pezzoli SS, Oliveri MC, Johnson ML, et al. Novel ghrelin assays provide evidence for independent regulation of ghrelin acylation and secretion in healthy young men. J Clin Endocrinol Metab 2008; 93: 1980-7. [CrossRef] 